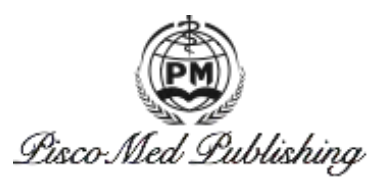

Original Research Article

\title{
Analysis of the Role of Macroeconomic Policies in the Financial Mar- ket Development
}

\author{
Haisheng $\mathrm{Hu}^{*}$
}

Chiang Mai University School of Public Policy, 11/F, Block B, Tongtai Building, 33 Financial Street, Xicheng District, Beijing 100000, China. E-mail: 564208752@qq.com

Abstract: Macroeconomics and microeconomics are two different categories of national economics, and both play vital roles in stimulating the economy. Especially in financial market development, they are interdependent and complement one another. Therefore, by starting with the status of national macroeconomic policies, this article analyzes the role of macroeconomic policies in the development of financial markets, and analyzes the practical cases, which can provide reference for the applied policies in the current financial market.

Keywords: Macroeconomic Policy; Financial Market; Monetary Policy; Fiscal Policy

\section{Introduction}

The whole world has fallen into economic crisis, and China has been in a special period of low tide. It is necessary to apply macro-control measures to control and improve economies in order to enhance the overall strength of the country and promote the sustainable development of the economy. Macroeconomic policies, especially in the constantly changing market environment, play a role in stabilizing the overall economic situation of society and driving the development of social and economic, which must be implemented in practical.

\section{The status of China's macroeconomic policies}

Only when the existing problems in the current financial market are fully clarified can the corresponding macroeconomic policies be put forward in a targeted manner. There has been a relatively short time since China's financial market established. Besides, the regulatory system is of problems to be solved. Therefore, it is necessary to pay attention to policy regulation in order to ensure the balance among financial market growth, liquidity and anti-inflation. The corresponding macroeconomic policies will be adopted after the interests of investors are protected. Macro-control was first appeared in the Third Plenary Session of the Eleventh Central Committee. With the development of China's economy, the contents are improved gradually, and its role in promoting economic development is gradually highlighted. Macroeconomic policies can be divided into fiscal policy, monetary policy, industrial policy, income distribution policy, foreign economic and trade policy and so on. When speaking promoting financial market, fiscal policy and monetary policy are considered as the two most effective aspects.

However, in the process of the financial development, various potential risks have been gradually emerged in China due to the negative impact of the global economic environment, and the harm to market development also has increased accordingly, which means people in China needs to face not only a short-term slowdown, but also a long-term

\footnotetext{
Copyright (C) 2020 Haisheng $\mathrm{Hu}$

doi: 10.18282/ff.v9i3.1101

This is an open-access article distributed under the terms of the Creative Commons Attribution Non-Commercial License

(http://creativecommons.org/licenses/by-nc/4.0/), which permits unrestricted non-commercial use, distribution, and reproduction in any medium, provided the original work is properly cited.
} 
downturn. The financial market is huge and complex, and consists of many branches and markets. Generally speaking, it can be divided into money market, that is, short-term and capital long-term financing market. It is also possible to further divide the two markets into finer sub-markets. Currently, the country has been committed to implementing macroeconomic policies in recent years, which has played a critical role in realizing the sustainable development of the financial market. After 2016, the international economy began to show a trend of slow upward, and more development space for monetary policy. Besides, the development trend of financial market became increasingly optimistic. It developed in a comprehensive, efficient and fair direction with the construction of macroeconomic policies under the favorable environment. Macroeconomic policies have certain guidance on financial market behavior. If investors rationalize their investment activities and restrain their investment behavior, they can effectively avoid mistakes in investment activities and reduce risks in financial markets. In practical application, some contents of macroeconomic policies can predict the development direction of financial markets. At the same time, they can reasonably restrain financial markets to avoid irrational cognition and market fluctuations by combining with investors' psychological thoughts. Except that, macroeconomic policies also break the traditional ideas, and make a comprehensive analysis on other factors in the financial market, which will not be confined to a single module of risk expectation, and make the financial market develop truly through diversified and comprehensive information resources. In this process, rational understanding of investors can be formed, which maintains the stable of the financial market, jointly build a good market environment for investment. Meanwhile, more economic benefits are created, and the market competitiveness of enterprises are improved, which promotes the national economy as a whole.

\section{The role and impact of macroeconomic policies on financial markets}

It can be seen from the above that monetary policy and fiscal policy maximize the role of financial market in macroeconomic policies. However, there are certain differences which are discussed as follows.

\subsection{The role and impact of monetary policy}

Monetary policy will change based on the money market. For example, the interest rate will increase when the RMB exchange rate increases accordingly. In this case, monetary policy can give full play to its role in regulating the financial market. It is the most basic macroeconomic policy, and is also the first choice for China to regulate and control the financial market, mainly by limiting the amount of money supplied to ensure the stable output of money, increase employment, and achieve the balance of payments. For China's stock market, monetary policy plays a vital role in two aspects. The first is to tighten policy. If the money supply is greatly reduced, it will restrict the stock and securities markets. The second is to ease policy. When the money supply increases, the stock market developed accordingly. However, it should be noted that the easing policy should moderate controlled financial markets, for which too much giving is likely to lead to inflation and threat to the development. Generally speaking, by using loans, risk-free interest rates, deposits and other forms to adjust the stock market, monetary policy mainly help China's financial market to achieve stable operation. In addition to the stock market, the bond market will also be affected by monetary policy, and the influence is mutual. The former can predict the future policy direction, while the latter can promote the bond market $^{[1]}$.

\subsection{The role and impact of fiscal policy}

Fiscal policy reflects the current economic development of an international country for a period of time. Its ways of regulating financial markets are mainly divided into active and dynamic aspects. At present, China's fiscal policy focuses on reducing economic fluctuations and inflation to create a good environment for entrepreneurship and employment. Fiscal policy, the main measure to regulate and control the financial market for Chinese government, includes common means like national debt and taxation. National debt is a national bond, which is issued by the central government to raise funds. Being different from bank credit, it exists as a regulating tool to transform financial credit into reality, and plays a certain role in regulating the financial market ${ }^{[2]}$. The risks and benefits in the domestic securities market 
are inseparable from the amount of government bonds issued. With the increasing of issuance of government bonds, the financial market expands and the activity increases. The financial market will, on the contrary, show a tightening situation. Generally speaking, national debt is an active financial means at the national level. It needs to be adjusted according to the national economic situation to stabilize and promote the development of financial market. Tax is also a tool and the most direct way to regulate the financial market. By taxation and regulation on the securities investors, the government will have a certain impact on the final income. If the tax increases, the profits of enterprises will decrease, and so does the investment funds, leading to a sharp decline in the trading funds invested in the securities year and the enthusiasm of investors. Comparatively speaking, with the reduction of tax revenue, investors' investment enthusiasm increases, which promotes the well-grow of financial market. That is to say, with the help of tax reuse and redistribution, it can effectively improve the financial market activity, and act as a certain supervisory role at the same time. Comparatively speaking, tax policy, to a certain extent, is mandatory and has the best effect on financial market supervision and regulation.

\section{Contents of macroeconomic policies applied in financial markets}

China's financial market is mainly regulated and controlled by fiscal policy and monetary policy to realize the steady development of the financial market. However, there are still many risks which will have a serious negative impact on the national economy. Therefore, in the new period, the financial market must be controlled by relevant government departments to actively implement macroeconomic policies and achieve healthy and sustainable development of the national economy.

\subsection{Monetary policy adjustment measures}

From the current development form of financial market, it is facing greater challenges. Only when the money market remains healthy can the financial market achieve sustainable development. Therefore, monetary policy needs to be optimized and adjusted to better meet the needs of financial market development from the following aspects.

First, to realize market-oriented interest rates. In the new era, monetary policy should provide diversified financial services to meet the actual needs of development to the greatest extent ${ }^{[3]}$. However, it should be noted that, in this process, the relevant departments should supervise the credit loan policy to ensure that the policy can be scientifically implemented, and make the flow of funds healthier in the financial market. Second, to control the deposit interest rate. In the current situation, deposit interest rates should be moderately innovated and flexibly adjusted to the market instead of unchange. Especially under the requirement of flexible delivery, the continuous deposit interest rate can further expand the open market business and stimulate the market vitality. Third, to standardize loan management. Loan is the main mode for monetary policy to regulate the financial market. The effectiveness of monetary policy can be improved by controlling the loan quota and implementing management measures. It is necessary to realize open and transparent management and give full play to the positive role of monetary policy.

Most of the above measures are discussed from the development environment of domestic financial markets. However, monetary policy should be analyzed from the development of international markets to ensure that monetary policy can always promote financial markets in the context of the economic globalization. Therefore, while implementing monetary policy, it is necessary to pay more attention to its actual effect. Corresponding transmission mechanism should be adopted, and some dredging measures moderately need to be carried out. For some time in the future, China need to focus on prudent monetary policy, so that the growth rates of currency, financing scale and nominal GDP can be kept at the same level. In addition, when implementing monetary policy, China should take care of every individual and enterprise, including private enterprises and small and micro enterprises, and truly achieve internal and external balance.

\subsection{The adjustment measures of fiscal policy}

In the practical development, it is necessary to strengthen the application of macroeconomic policies and provide 
scientific and effective policy strategies in order to ensure the rapid, healthy and stable development of financial market. Investors can also make reasonable investments at the same time. China's debt and taxation play a vital role in fiscal policy. Therefore, China need to focus on the following aspects in the process of optimization and adjustment.

Firstly, in terms of treasury bonds, long-term treasury bonds should be issued moderately to meet the development needs of financial markets each year. The expansion and contraction of the financial market will be realized by adjusting the increase or decrease of treasury bonds, which will arouse the investment enthusiasm of investors and enable investors to have certain rationality. Secondly, in terms of loans, it is necessary to guide and manage enterprise loans, and control them within a reasonable range. In this case, the risks that banks need to bear can be reduced, and the stable development of the financial market can be constrained. In terms of taxation, tax policy should be implemented in accordance with laws and regulations to increase national fiscal revenue ${ }^{[4]}$. The development of financial market can not be separated from perfect tax system. Besides, the tax system of foreign market should also be improved based on practical situation. Flexible schemes should be worked out and adjusted regularly to make the financial market develop continuously.

On the basis of the stable development of the financial market, fiscal policy should link with monetary policy. A policy coordination mode with finance as the mainstay and money as the supplement should be formed to bring more vitality to the market. It is also necessary to promote the transformation and development of fiscal policy to a stable policy system based on the constantly improving the innovation policy. The macroeconomic policies can therefore be truly developed and a fundamental guarantee for the safety of financial market funds can be provided.

\section{Conclusion}

In summary, in the era of economic globalization, the government must have a deep understanding of that the non-ignorable role of financial markets, and flexibly adjust various policies to ensure that the role of policies in the development of financial markets is maximized. In macroeconomic policies, monetary policy and fiscal policy are the two most critical elements. Therefore, it is necessary to focus on optimizing and adjusting these two. Meanwhile, supervision and risk prevention measures need to be implemented to promote the development of financial markets in practical.

\section{References}

1. Yang F. Analysis of the role of macroeconomic policies in the development of financial markets (in Chinese). PR Magazine 2020; (7): 289-290.

2. Gu Y. On the role and influence of macroeconomic policies in financial markets (in Chinese). China Collective Economy 2020; (16): 111-112.

3. Yang Y. On the role of macroeconomic policies in promoting the development of financial markets (in Chinese). Chinese \& Foreign Entrepreneurs 2020; (9): 88.

4. Ma J, Li Z. The role and influence of macroeconomic policies in financial markets (in Chinese). Shanxi Agricultural Economy 2020; (1): 28-29. 